22 MacPike, E. F., "Correspondence and Papers of Edmond Halley" (Oxford, 1932; London, 1937).

28 MacPike, E. F. "Hevelius, Flamsteed and Halley" (London, 1937); see also MacPike, E. F., "Dr. Edmond Halley, a Bibliographical Guide" (London: Taylor and Francis, 1939).

24 Or possibly in 1657 ; see ref. $23, \mathrm{p} .34$.

${ }^{2 s}$ Phil. Trans., 208 (1683).

${ }^{20}$ Phil. Trans., 563 (1692).

${ }^{27}$ Journal Book of the Royal Society ; see Terr. Mag., 18, 118-121 (1913).

28 See ref. 22, p. 97.

${ }^{29}$ Des Cartes, R., "Principia Philosophiæ" (Amsterdam, 1644).

:0 Bond, Henry, "The Longitude Found" (London, 1676).

${ }^{31}$ Ref. 25 , \& 9.

${ }^{32}$ Ref. 25 ; here abridged.

s3 See ref. 22, pp. 135-137; these experiments are discussed in detail by A. C. Williams, "Edmond Halley and the Problems of Terrestrial Magnetism"' (London University Dissertation, 1937).

${ }^{84}$ Copies of Yeates' chart are in the British Museum Library (Catalogue No, 974 (2) ) and the Admiralty Library.

s s See ref. 22, p. 186 (Hooke's notes for Jan. 11, 1692/3 and April 12, $1693)$, also footnote 2

s6 See ref. 22, pp. 8, 9, 21, 22, 103-115, 243-247, for much interesting information on Halley's magnetic voyages.

37 See ref. 4.

${ }^{38}$ The method had previously been used by Christopher Burro, who made an isogonic chart mentioned by Kircher (loc. cit., p. 443)

${ }^{30}$ See ref. 22, p. 201 , and ref. 23 , p. 60 .

\section{MORE AND BETTER MILK}

T is common knowledge that while the average diet in most European countries has been seriously worsened by the War (in certain countries it is reported to have been deliberately reduced by the Nazis well below the minimum subsistence-level), the present diet in Great Britain, though drab and much restricted as to choice of food, is still from the point of view of the nutritional scientist little, if at all, inferior to pre-war standards. In fact, as a result of the rationing system and the more even distributicn of purchasing power, it is probably true that the great majority of our population is better (or perhaps one ought to say less badly) fed than before the War.

That this is so is due in no small part to the facts that it has been possible $(a)$ to maintain the total home production of milk at its pre-war level; $(b)$ to increase considerably the quantity of liquid milk consumed (at the expense of milk which was, in prewar days, manufactured into products valuable and delectable in themselves but the preparation of which entailed very considerable losses of nutritive value in the shape of whey and skimmed milk, little of which was consumed by the human population); and (c) to increase slightly the amount of liquid milk produced in winter when milk is more difficult and economically more costly to produce than in summer. As regards (b), during the last three years the yearly liquid milk intake in Britain has risen until it is now about 40 per cent above pre-war level. This is a continuation of a tendency that was clearly evident before the outbreak of war. In 1938, for example, the liquid milk consumption per head in England and Wales rose by 11 per cent.

For the first time in our history a comprehensive Government milk policy, in which the Ministries of Food, Health and Agriculture are collaborating, is now in action, based on the key nutritional importance of milk' in the war-time dietary. A number of different but associated schemes have been introduced to implement that policy. They include on the consumption side an extension of the pre-war milk-inschools scheme, the legislation for giving priority of liquid milk supplies at reduced cost to expectant and nursing mothers and children less than five years of age and to certain classes of invalids, and on the production side the priority given to dairy cows in the animal feeding stuffs rationing scheme, the nationwide drive through the County War Agricultural Executive Committees to stimulate milk production, the voluntary 'panel' scheme arranged a few months ago between the Ministry of Agriculture, the National Farmers' Union and the National Veterinary Medical Association for the control of certain diseases affecting dairy cows, the national milk testing and advisory scheme to prevent milk souring and to disseminate knowledge of methods of clean milk production on the farm and of hygienic milk handling off the farm, together with national schemes for milk recording and live-stock improvement.

A joint meeting of the Nutrition Society and the Food Group of the Society of Chemical Industry took place at the London School of Hygiene on July 3 to review the nutritional aspects of these and other recent developments and trends in milk policy. The chairman (Prof. H. D. Kay), in his introductory remarks, pointed out that the future of national nutrition is bound up to a great extent with milk production, and that the future of milk production is in a very real way the future of British farming. He emphasized the present difficulties under which milk producers were working, and pointed out the urgent need for improved technical training both for the future dairy farmers and for those entering the technical and scientific side of the milk processing and distribution industry. For the latter entrants there was at present, as before the War, scarcely any advanced voeational training in Great Britain.

The first paper was given by Mr. J. L. Davies, on the production, supply and marketing of milk. $\mathrm{He}$ emphasized the enormous size of the milk industry, with a capital estimated (in pre-war values) at $£ 350-$ $£ 400$ millions, and with between 400,000 and 500,000 people actually engaged in milk production, processing and distribution, apart from those in the ancillary industries of feeding stuffs, manufacture and production of dairy machinery, equipment, etc. Of the herds owned by our 150,000 dairy farmers, 36 per cent contained less than 10 cows, 45 per cent 10-25 cows; 15 per cent contained 25-50 cows and only 4 per cent contained more than 50 cows. While the average yield of milk per cow had gone down since the War, he considered that the pre-war average milk yield for the cow in the older established dairying herds was considerably greater than the average for the whole country (which included some herds mainly kept for breeding and rearing purposes), say, 600-650 as against the total country average of 500-550 gallons. There was room for improvement in yield and in methods of milk production, and steps were now being made through W.A.E.C.s to achieve as much as was possible in war-time. Mr. Davies suggested a ten-year plan, to rebuild and re-equip our dairy farms, to bring water supplies and electricity to them, and to render them relatively disease-free. He advocated a six-day (and not, as at present, a seven-day) week on the dairy farm. His ten-year plan would include the steady raising of milk consumption to at least 0.75 pint per head per day accompanied, of course, by the same increase in milk production, which he was sure the industry could provide during the same period. He considered we should plan now. 
In the discussion on this paper, Dr. Wooldridge emphasized the importance of disease control on the farm. Disease placed a high and unnecessary tax on the economic cost of milk production. Prof. A. W. Ashby, while supporting the need for greater efficiency in the industry, which could only be achieved by national planning, considered that the economic effect of disease was exaggerated. Dr. Stableforth held the opposite view. Mr. Davies' paper and the discussion which followed took up the whole of the morning session.

In the afternoon, Dr. A. T. R. Mattick dealt with the bacteriological aspects of milk processing. Pasteurization, if properly carried out, both greatly increased the keeping quality of milk and destroyed all the common pathogenic organisms that might occur in raw milk. The difficulty was to ensure that pasteurization was properly carried out. For public health reasons there should be filtration of the milk before pasteurization. The provisional regulations for the new attractive alternative of high-temperature shorttime pasteurization (not less than $162^{\circ} \mathrm{F}$. for not less than fifteen seconds) allowed a margin of safety, but the thermometric apparatus controlling flow diversion valves lacked, in some machines, speed of response to changes in temperature. $\mathrm{He}$ discussed recent findings on the occurrence in milk of pathogenic and other organisms. Aseptically drawn milk from healthy animals contained only micrococei and Corynebacterium sp., organisms which did not survive ordinary pasteurization. In fact the organisms in cleanly but not aseptically drawn milk were all vulnerable to pasteurization. This was not the case with raw milk reaching the average pasteurization plant, in which heat-resistant organisms were of frequent occurrence. The bacterial quality of raw milk seriously affected the bacterial quality of the milk after pasteurization. Dr. Mattick very much doubted the value of the plate count as a measure of efficient pasteurization. He considered that there was much room for improvement in the design of bottle-filling and bottle-washing machines. With improved methods of production and control on the farm, coupled with improvements in processing technique and particularly in the manipulation of milk after heat treatment, "we have the possibility of furnishing the people with a product of such superb quality as is at present visualized only by the few".

Dr. S. K. Kon followed with a paper on the chemical composition and nutritive value of milk and milk products. This paper gave a wealth of recent quantitative findings impossible to summarize in a review. Milk varied in chemical composition and nutritive value not only with the breed and health of the cow, but in the same healthy cow from one season of the year to another. The diet of the cow was largely responsible for changes in the vitamin A content of milk and to a lesser extent for the changes in riboflavin; but vitamin $B_{1}$, which was synthesized in the bovine rumen, was fairly constant in quantity throughout the year. Vitamin $\mathrm{C}$ was synthesized by the cow, but unlike the B vitamins the synthesis did not take place in the rumen. It was unfortunate that milk was lowest in vitamin content in early spring, since most other human foodstuffs were at that season at their nadir of nutritional value. $\mathrm{He}$ considered that more attention should be paid in future to nutritive quality of milk produced in Great Britain.

The effect on the nutritive value of milk of pasteurization, sterilization, drying and condensing was stated in some detail by Dr. Kon. Commercial pasteurization brought about a loss of vitamin $\mathrm{C}$ of the order of 20 per cent, caused rather by exposure of the milk to light than to heat, and a still smaller percentage loss of vitamin $B_{1}$ but no other change of nutritional significance. The effect of sterilization was rather larger-a loss of half the vitamin $\mathrm{C}$ and one third of the vitamin $B_{1}$. There is, in any event, little vitamin $\mathrm{C}$ in cow's milk, and not very much $\mathrm{D}$. But even the small quantity of vitamin $\mathrm{C}$ in a pint bottle of raw milk was halved if the bottle' was left on the doorstep in full daylight for half an hour; destruction was still more rapid in sunlight. Spray drying of milk led to a very small loss in nutritive value, of the same order as that caused by pasteurization. Roller drying brought about rather larger losses. Vitamin $\mathrm{A}$ and carotene, vitamin $\mathrm{D}$ and riboflavin suffered no loss during drying. Among other important points Dr. Kon emphasized the nutritional importance of the by-product from butter manufacture-skim milk. Dried skim milk ("National Household Milk') was an excellent food for all ages except early infancy.

The discussion on these two papers was opened by Prof. G. S. Wilson, who stressed the great difficulty that responsible medical men had in advocating the increased consumption of milk unless the latter had previously been efficiently pasteurized. He dealt with the human diseases that might be conveyed by raw milk, and exploded several of the arguments brought forward by the opponents of compulsory heat-treatment of milk. A lively discussion followed, in which Mr. A. L. Bacharach, Dr. H. E. Magee, Dr. N. S. Barron, Dr. W. A. Lethem, Captain H. Barkworth, Prof. J. R. Marrack, Dr. Kent-Jones and others took part. Perhaps too much attention was paid in the discussion to the pasteurization problem-the major facts concerning which are well known. In consequence, some of the important bacteriological and nutritional points made by the principal speakers in the afternoon session were crowded out.

In summing up, Prof. Kay stated that the real war-time problem was to get to every consumer the maximum quantity of safe winter milk, and he emphasized the great contribution that dairy farmers and those advising them and directing their efforts had made in maintaining the national winter milk supply during the War. There seemed to be no dissentients in this representative meeting of nutritionists (nearly three hundred were present during the afternoon session) to the view that general heat treatment of milk was highly desirable, in fact overdue, and that not least from the point of view of the true interests of the producer. It was also clear that the meeting fully agreed with the importance of increased consumption of liquid milk, and that the objective should be an average of not less than 1 pint per head per day. 'There was general agreement that one of the questions of greatest moment at present from the point of view of national nutrition was how the trend, clearly evidenced during the War, towards increased per capita milk consumption was to be maintained in the post-war period until this objective was achieved. Planning for increased post-war production and consumption should begin forthwith. There were three sides at least to this question, the producer's, the distributor's and the consumer's, and better technical training for all three, not excluding the frequently forgotten consumer, was urgently needed if this problem were to be solved in a reasonable time. 